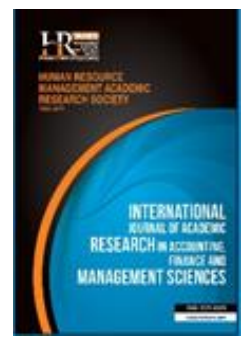

International Journal of Academic Research in Accounting, Finance and Management Sciences

Vol. 9, No.3, July 2019, pp. 287-294

E-ISSN: 2225-8329, P-ISSN: 2308-0337

(C) 2019 HRMARS

www.hrmars.com

To cite this article: Qubbaja, A., Omar, S.A. (2019). The Impact of Political Events on Palestine Securities Exchange

Returns: An Empirical Study between (1997-2016), International Journal of Academic Research in Accounting,

Finance and Management Sciences 9 (3): 287-294

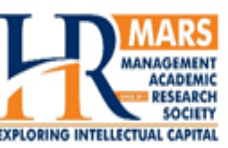

http://dx.doi.org/10.6007/JARAFMS/v9-i3/6482

(DOI: 10.6007/IJARAFMS/v9-i3/6482)

\title{
The Impact of Political Events on Palestine Securities Exchange Returns: An Empirical Study between (1997-2016)
}

\author{
Adnan Qubbaja ${ }^{1}$, Subhi Abu Omar ${ }^{2}$ \\ ${ }^{1}$ Financial and Banking Science Department, Palestine Ahliya University, E-mail: aqubbaja@paluniv.edu.ps(Corresponding author) \\ 2Palestine Red Crescent-Financial Department, E-mail: Subhi2384@gmail.com
}

\begin{tabular}{|c|c|c|}
\hline Abstract & \multicolumn{2}{|c|}{$\begin{array}{l}\text { This study intends to find the impact of political events on stock return of Palestine Securities Exchange } \\
\text { returns (Al-Quds Index). A total of Twenty Seven Political events have been considered between (1997-2016), } \\
\text { political events divided into two groups i.e. favorable and unfavorable political events. The impact is checked } \\
\text { for favorable and unfavorable political events for } 1 \text { day, } 5 \text { days, } 10 \text { days, } 15 \text { days and } 20 \text { days, events } \\
\text { windows. Favorable and unfavorable political events show no impact on stock returns using } 1 \text { day, } 5 \text { days, } 10 \\
\text { days, } 20 \text { days event windows; Regression model indicates that there is no significant impact of the political } \\
\text { events on the Index returns. Moreover, analysis can be done on the industry level to separately inspect } \\
\text { separately the impact of these events on individual stock or on portfolios. }\end{array}$} \\
\hline Key words & \multicolumn{2}{|c|}{ Political events, Palestine Exchange, Stock Return, Favourable and Unfavourable Events, Levene's Test } \\
\hline Received: & 30 Sep 2019 & (C) The Authors 2019 \\
\hline Revised: & 14 Oct 2019 & Published by Human Resource Management Academic Research Society (www.hrmars.com) \\
\hline $\begin{array}{l}\text { Accepted: } \\
\text { Published Online: }\end{array}$ & $\begin{array}{l}19 \text { Oct } 2019 \\
30 \text { Oct } 2019\end{array}$ & $\begin{array}{l}\text { This article is published under the Creative Commons Attribution (CC BY 4.0) license. Anyone may } \\
\text { reproduce, distribute, translate and create derivative works of this article (for both commercial and } \\
\text { non-commercial purposes), subject to full attribution to the original publication and authors. The full } \\
\text { terms of this license may be seen at: http://creativecommons.org/licences/by/4.0/legalcode }\end{array}$ \\
\hline
\end{tabular}

\section{Introduction}

Undoubtedly, political events in the contemporary world greatly affect stock market of every country. Their impact, which is fundamental for economy as a whole, can be found easily on micro- and macro-levels of the economic system. Recently, there were a huge number of significant political events that affected the majority of life aspects inside and outside countries. Their essential exposure on prices of trading assets was also repeatedly admitted. This is the reason why the precise estimation of such events is a vital component of successful operation in the market for both investors and market specialists (Center for Strategic and International Studies, 2017).

The impact of political events on financial market performance has been a significant debatable over the last years. The relationship between political events and stock markets has been widely examined in the empirical literature, especially after the recent financial crisis (Diamonte et al., 1996) and (Lehkonen and Heimonen, 2015), indicate that any reduction in the political risk can lead to higher portfolio and stock returns. Li and Born (2006) also provide evidence of a strong relationship between the elections and the financial markets. Addoum and Kumar (2016) examine the effects of the political climate changes on financial market outcomes.

To bridge the gap in scientific knowledge, the researchers' goal is to study the peculiarities of political events' influence on price dynamics on Palestine exchange between (1997-2016). More precisely, the researchers' will examine and analyze their impact on return and volatility of market indices. This 
research has a marked theoretical and practical significance that allows researchers and market experts to obtain the most accurate and perfect idea of the impact design of political events on the Palestine exchange (PEX).

\subsection{Research Problem}

The general effect of political events on stock exchange has been increased volatility of stock prices around political events. This is mostly attributed to the uncertainty that surrounds such events with most investors find it hard to make investment decisions during these political events. Although there has been enormous study on the effect of political events on stock markets in developed countries, few studies have been conducted on developing markets. Since PEX (Palestine Exchange) is considered as a newly emerging financial market, no research was conducted on the reaction of PEX to political events. Therefore, this study builds on the previous works through analyzing the impact of political events on stock returns at PEX between (1997-2016).

\subsection{Research Objectives}

The study attempts to achieve the following objectives:

1. To examine the impact of political events on stock returns in PEX (AL-QUDS INDEX).

2. To examine whether there are abnormal returns around events date.

\subsection{Research Hypotheses}

Based on the previous discussion, the researcher forms the following hypotheses:

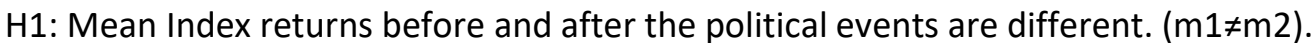

$\mathrm{H} 2$ : Mean Index returns before and after the favorable political events are different. ( $1 \neq m 2)$.

H3: Mean Index returns before and after the unfavorable political events are different $(\mathrm{m} 1 \neq \mathrm{m} 2)$.

\section{Literature review}

\subsection{The Relationship between Political Risk and Stock Prices}

Political changes that arise from the collapse of communism, the execution of market-oriented economic and financial reforms have resulted in a huge amount of external capital flowing into the emerging markets of Eastern Europe, Latin America, Asia, and Africa (Ramcharran, 2003). These events have alarmed international investors about the reality that globalization of world trade and open capital markets is risky and can result in financial crisis that spread rapidly and can prove to be a destabilizing factor for the international financial sector (Hayes, 1998). Political risk emanates from the uncertainty that relates to exercise of power by governments and its consequences. Non-governmental actors in a country can also trigger political risk.

Many scholars examined the relation between political events risk and stock prices not only in the context of developed countries but also in the emerging ones. For example, Wang and Lin investigated the response of stock market to political uncertainty during congressional sessions in Taiwan. The objective of the paper was to find answers for three questions including whether or not congressional sessions exert an influence on stock returns and volatility, whether or not democratization (as reflected by the democratically presidential election in Taiwan) influences stock returns and volatility, and whether or not the interaction effect between congressional and democratization influences stock returns and volatility (Wang and Lin, 2009).

\subsection{Palestine Securities Exchange (PEX)}

Palestine Exchange (PEX) was established in 1995 to promote investment in Palestine. The PEX was fully automated upon establishment- a first amongst the Arab Stock Exchanges. The PEX became a public stockholding company in February 2010 in response to principles of transparency and good governance. The PEX operates under the supervision of the Palestinian Capital Market Authority.

There are 48 listed companies on PEX with market capitalization of about $\$ 3$ billion across five main economic sectors; banking and financial services, insurance, investments, industry, and services. Most of 
the listed companies are profitable and trade in Jordanian Dinar, while others trade in US Dollars. Only stocks are currently traded on PEX, but there is a potential and readiness to trade other securities in the future. In 2009, the PEX was ranked thirty third amongst the worldwide security markets, and regionally comes in second in terms of investor protection.

\subsection{Previous Studies}

Hira (2017) examined the effects of political uncertainty on corporate investing behaviors by analyzing the change in stock prices resulting from the uncertainty in the political system. The study concentrates on the relationship between stock prices and political instability. Political instability was measured by different factors, such as strikes, assassinations, riots, demonstrations, government longevity, government change, and regime type. Results of the study indicated the existence of a negative relationship of stock prices with political instability.

Nikolayevich et al. (2017) has set the aim to investigate the Russian market by using GARCH models. By using such approach, they were allowed to precisely determine the influence of political events on return and volatility of market assets. Research has demonstrated that political events have a significant impact on price dynamics of financial assets of Russian stock market. Moreover, it was confirmed that positive political events exert significant impact on return increase of Russian stock market, and negative events - on return decrease. The increase of MICEX index quotes in a day with positive events is consistently higher than price increase a day before. Correspondingly, in case of negative events, market returns decrease significantly in a day of their appearance.

Asteriou and Sarantidis (2016) examine the relationship between political events and stock market returns by using quarterly time series data from 1993 to 2013. In this paper, stock market returns are defined as returns of the general stock market index and banking index for 18 OECD countries. Five different political events indicators were constructed to measure political uncertainty. The empirical part utilizes the EFA, PCA and GARCH-M methodologies. The findings indicate a direct and an indirect impact between the indicators of political events, returns of the Banking Index, and the Overall Stock Market Index.

In their paper Najaf et al. (2015) aimed to explore the relationship between political events in Pakistan on the stock market development. The paper presents data concerning the reaction of financial markets to the political events in Pakistan between (2011-2014). T-statistic is used to measure the impact of political events on stock exchange market. In order to determine the Average return (AR), moving average method was used. The results of the study shown no existence of significant relationship between stock market returns and Political events.

Lam and Zhang (2014) investigated the impact of policy uncertainty on stock returns in 49 developed and emerging markets during the period 1995-2006 by constructing two global policy uncertainty measures. Government stability and bureaucracy quality data were obtained from the ICRG to construct these two measures. They used the Zero Investment Strategy for the country level portfolios from their policy uncertainty measures. They sorted the countries monthly according to low minus high government stability and bureaucracy quality respectively. By doing this, they have two types of stock returns according to policy uncertainty. Their results confirm that policy uncertainty measures significantly affect the returns. They found out one standard deviation increase in the bureaucracy quality increase the returns of $27 \%$ per year whereas for the government stability is $7.8 \%$.

\section{Methodology of research}

Two different variables are involved in this, political events as an independent variable and stock returns as dependent variables. Political events are measured by dummy variables. Days before the events, these events took the value of (0) while after the events; they took the take value of (1). This study used stock returns as a dependent variable since it attempts to check whether stock returns are affected by political events or not. (AL-QUDS INDEX) stock returns before and after the occurrences of political events were collected and investigated.

This study used logarithmic return to solve the problem of unit root making data stationary: $R_{t}=1 n$ $\left(P_{t} / P_{t-1}\right)$ where: 
$R_{t}=$ is a logarithmic return

$\mathrm{P}_{\mathrm{t}}=$ current day return

$\mathrm{P}_{\mathrm{t}-1}=$ previous day return

Political events that happened from (1997-2016) are also considered in this study. The motive behind selecting this time frame is Palestine volatile political structure during these years.

\subsection{Data Collection and Analysis}

To test the hypotheses, secondary data has been used. It required two kinds of data, one about stock prices and the other is about political events. Data about PEX stock returns has been obtained from PEX. It consists of total (7481) observations between (1997-2016). Data about political events has been obtained from Palestine's leading newspapers and some international sources.

\subsection{Research Model}

Political Events

Figure 1. Research Model

\subsection{Definition of Key Terminologies}

Palestine Securities Exchange: The PEX was established in 1995 by PADICO as a gate for financial market exchange. Its capital is more than \$3billion as of 2012 and is continuously growing. It offers both Palestinian and international investors with the chance to invest in both locally held and internationally funded corporate through their issued stocks in the market.

Political Events: A type of risk that faces investors, corporations, and governments whose political decisions, events, or conditions will significantly affect the profitability of a business actor or the expected value of a given economic action.

Favorable political Events: A type of risk that faces investors, corporations, and governments whose political decisions, events, or conditions will positively affect the profitability of a business actor or the expected value of a given economic action (Bremmer, 2007).

Unfavorable political Events: A type of risk that faces investors, corporations, and governments whose political decisions, events, or conditions will negatively affect the profitability of a business actor or the expected value of a given economic action (Bremmer, 2007).

\subsection{Research design}

The study was based on Event Study Methodology to establish the behavior of stock return between (1997-2016). The event window constricted one day, 5 day, 10 days, 15 days and 20 days before and after event.

\subsection{Events Identification}

Political events from 1997 to 2016 were under examination for the purpose of this research. The selection is made by analyzing the event's intensity that is measured by examining its importance in the front pages of the leading newspapers. The headlines of the political events are gathered and the events are selected for analysis which has given the same prominence in all leading newspapers. The data regarding daily closing index of Palestine stock market was collected from website of Palestine Stock Market. The daily closing index was gathered from 1997 to 2016.

\subsection{Event Window}

The event window selection is an empirical issue. It is a too long window that will absorb the impact of other economic, non-economic, and political events that are out of interest for this research, in addition to a window that is too short and which will not be able to analyze the effect of an event. To avoid the 
impact of other events on the research, the researcher used event windows one day, 5 day, 10 days, 15 day and 20 days before and after an event for analysis.

Table 1. List of Political Events

\begin{tabular}{|c|c|c|c|c|}
\hline $\begin{array}{c}\text { Serial } \\
\text { number }\end{array}$ & Date & Political Event & $\begin{array}{l}\text { Al-Quds } \\
\text { Index Change }\end{array}$ & $\mathrm{F} / \mathrm{u}$ \\
\hline 1 & 25/09/1997 & $\begin{array}{l}\text { Mossad agents failed in an attempt to kill Hamas member Khaled } \\
\text { Mashal in Amman }\end{array}$ & 103.80 & $U$ \\
\hline 2 & 23/10/1998 & $\begin{array}{l}\text { Benjamin Netanyahu and Yasser Arafat signed the Wye River } \\
\text { Memorandum. }\end{array}$ & 160.27 & $\mathrm{~F}$ \\
\hline 3 & 17/05/1999 & Ehud Barak of the Labor Party elected Prime Minister. & 165.99 & $\mathrm{~F}$ \\
\hline 4 & $28 / 09 / 2000$ & $\begin{array}{l}\text { Arafat named the second intifada the Al-Aqsa Intifada after } \\
\text { Sharon's visit, for the Al-Aqsa Mosque. }\end{array}$ & 260.98 & $U$ \\
\hline 5 & 06/02/2001 & $\begin{array}{l}\text { Ariel Sharon of Likud elected Prime Minister and refused to } \\
\text { continue negotiations with Yasser Arafat at the Taba Summit. }\end{array}$ & 201.96 & $U$ \\
\hline 6 & $27 / 08 / 2001$ & $\begin{array}{l}\text { Abu Ali Mustafa, was assassinated by an Israeli missile shot } \\
\text { through his office window in Ramallah. }\end{array}$ & 151.10 & $\mathrm{U}$ \\
\hline 7 & 05/06/2002 & $\begin{array}{l}\text { Israel began construction of the Israeli West Bank barrier to } \\
\text { prevent Palestinian entering Israel. }\end{array}$ & 175.80 & $U$ \\
\hline 8 & 19/03/2003 & $\begin{array}{l}\text { Mahmoud Abbas appointed Prime Minister of the Palestinian } \\
\text { National Authority. }\end{array}$ & 145.70 & $\mathrm{~F}$ \\
\hline 9 & $30 / 04 / 2003$ & $\begin{array}{l}\text { The "Road Map for Peace" is presented by the Quartet to the } \\
\text { Israelis and Palestinians. }\end{array}$ & 203.07 & $\mathrm{~F}$ \\
\hline 10 & $22 / 03 / 2004$ & $\begin{array}{l}\text { Israeli occupation rocket killed Hamas leader Ahmed Yassin and } \\
\text { eleven others in Gaza City. }\end{array}$ & 181.90 & $U$ \\
\hline 11 & $11 / 11 / 2004$ & Yasir Arafat dies in a Paris hospital & 252.66 & $U$ \\
\hline 12 & $13 / 01 / 2005$ & Karni border crossing attack. Palestinian killed 6 Israeli & 277.73 & $U$ \\
\hline 13 & $25 / 01 / 2006$ & $\begin{array}{l}\text { Hamas won by landslide the majority of seats after the Palestinian } \\
\text { legislative election. }\end{array}$ & 1022.17 & $U$ \\
\hline 14 & $12 / 07 / 2006$ & $\begin{array}{l}\text { Lebanon War: Hezbollah infiltrated Israel in a cross-border raid, } \\
\text { captured two soldiers and killed three others. }\end{array}$ & 520.60 & $U$ \\
\hline 15 & 09/01/2007 & $\begin{array}{l}\text { Israel releases } \$ 100 \text { million in tax revenues, to cover the } \\
\text { humanitarian needs and other basic expenses of the Palestinians. }\end{array}$ & 592.89 & $\mathrm{~F}$ \\
\hline 16 & $28 / 02 / 2008$ & $\begin{array}{l}\text { Operation "Hot Winter" began. The operation resulted in } 112 \\
\text { Palestinians and three Israelis being killed. }\end{array}$ & 599.69 & $U$ \\
\hline 17 & $24 / 12 / 2009$ & $\begin{array}{l}\text { Rabbi Meir killed in a drive-by shooting Al-Aqsa Martyrs' Brigades } \\
\text { claimed responsibility. }\end{array}$ & 486.01 & $U$ \\
\hline 18 & $14 / 09 / 2010$ & $\begin{array}{l}2010 \text { direct talks: A second round of Middle East peace talks } \\
\text { between Israel and the Palestinian }\end{array}$ & 500.09 & $\mathrm{~F}$ \\
\hline 19 & $18 / 12 / 2010$ & American woman stabbed to death by Palestinian. & 486.59 & $\mathrm{U}$ \\
\hline 20 & $07 / 11 / 2011$ & Palestine won membership of UNESCO. & 472.85 & $\mathrm{~F}$ \\
\hline 21 & $14 / 11 / 2012$ & Israeli occupation killed Ahmed Jabari & 456.79 & $U$ \\
\hline 22 & $15 / 1 / 2013$ & Four Palestinians were killed by Israeli occupation within a week & 469.14 & $U$ \\
\hline 23 & $23 / 04 / 2014$ & $\begin{array}{l}\text { Palestinian Authority (Fatah) and Hamas sign reconciliation } \\
\text { agreement to create a Palestinian unity government. }\end{array}$ & 533.20 & $\mathrm{~F}$ \\
\hline 24 & 03/10/2015 & $\begin{array}{l}\text { The young man Muhannad Halabi stabs a settler in the Asbat Gate } \\
\text { in the Old City of Jerusalem. }\end{array}$ & 479.20 & $U$ \\
\hline 25 & $13 / 11 / 2015$ & $\begin{array}{l}2 \text { Israeli civilians killed and } 1 \text { wounded in shooting attack near } \\
\text { Hebron }\end{array}$ & 506.55 & $U$ \\
\hline 26 & 08/06/2016 & $\begin{array}{l}\text { Two Palestinian gunmen opened fire at a Max Brenner Cafe, killing } \\
\text { four people and injuring seven others. }\end{array}$ & 497.46 & $U$ \\
\hline
\end{tabular}




$2711 / 12 / 2017 \begin{aligned} & \text { USA President Donald Trump recognizes Jerusalem as the capital } \\ & \text { of Israel. }\end{aligned} 558.52 \quad \mathrm{U}$

F: Favorable/U: Unfavorable

4 .Results and analysis

\subsection{Descriptive Statistics of the Data Being Used}

Table 1. Descriptive Statistics

\begin{tabular}{ccccccc}
\hline Observations & Mean & Standard Deviation & Minimum & Maximum & Skewness & Kurtosis \\
\hline 7481 & 0.0002333 & 0.01057854 & -0.16956 & 0.18336 & 0.495 & 32.188 \\
\hline
\end{tabular}

The data consisted of 7481 observations collected from (9/7/1997) to (31/12/2017). The mean value for logarithmic returns was 0.0002333 with a minimum value of -0.16956 and maximum value of 0.18336 . The disparity in the minimum and maximum values for the data shows the wide range in stock returns on different days. The standard deviation is $1.057854 \%$ which means that the data has some deviations from the average value. Also, Kurtosis of 32.188 suggested the data to be slightly leptokurtic. The data has a skewness of 0.495 , which is close to 0 suggesting the data to be normal.

\subsection{Testing the Hypothesis}

\subsubsection{Impact of Political Events}

Table 2. Empirical Results for Political Events

\begin{tabular}{cccccc}
\hline TEST & 1-day Window & 5-days Window & 10-days Window & 15-days Window & 20-days Window \\
\hline Levene's Test value & 0.037 & 0.008 & 0.273 & 0.361 & 1.536 \\
\hline P-value & 0.849 & 0.931 & 0.603 & 0.551 & 0.221 \\
\hline
\end{tabular}

Levene's Test was conducted to find if the data would consider t-value for assumed or non-assumed equal variances. Referring to Table 2 the P-value using 1-day, 5-day, 10-day, 15-days, and 20-day respectively is $0.849,0.931,0.603,0.551$, and 0.221 . This value is greater than $5 \%$ which means that stock returns before and after political events were not different. So, there is no impact of political events on stock returns using Event Window.

\subsubsection{Impact of favorable political events}

Table 3. Empirical Results for Favorable Political Events

\begin{tabular}{cccccc}
\hline TEST & 1-day Window & 5-days Window & 10-days Window & 15-days Window & 20-days Window \\
\hline Levene's test value & 0.052 & 0.002 & 0.059 & 0.283 & 0.268 \\
\hline P-value & 0.823 & 0.967 & 0.812 & 0.603 & 0.613 \\
\hline
\end{tabular}

Referring to Table 3 the P-value using 1-day, 5-day, 10-day, 15-days, 20-day respectively event window is $0.823,0.967,0.812,0.603$, and 0.613 . This value is greater than $5 \%$ which means that stock returns before and after favorable political events were not different. So, there is no impact of favorable political events on stock returns using 1-day, 5-day, 10-day, 15-days, and 20-day window.

\subsubsection{Impact of Unfavorable Political Events}

Table 4. Empirical Results for Unfavorable Political Events

\begin{tabular}{cccccc}
\hline TEST & 1-day Window & 5-days Window & 10-days Window & 15-days Window & 20-days Window \\
\hline Levene's test value & 1.279 & 0.036 & 0.552 & 0.078 & 1.099 \\
\hline P-value & 0.265 & 0.851 & 0.462 & 0.782 & 0.302 \\
\hline
\end{tabular}

Referring to Table 4 the P-value using 1-day, 5-day, 10-day, 15-days, 20-day respectively window is $0.265,0.851,0.462,0.782$, and 0.302 . This value is greater than $5 \%$ which means that stock returns before 
and after unfavorable political events were not different. So, there is no impact of unfavorable political events on stock returns using 1-day, 5-day 10-day, 15-days, 20-day window.

Since Levene's test show that the average closing prices are homogeneous before and after the most recent political events, study try to find out whether the reason for the homogeneity is due to the price adjustment or to inefficiency of Palestine Stock Exchange, Regression model in Table 5 indicates that there is no statistically significant impact of the political events on the Index returns.

Table 5. Regression Model Results

\begin{tabular}{cccc}
\hline Constant & $\mathbf{0 . 0 0 0 2 4 3}$ & $\mathbf{( R )}$ Coefficient of correlation & $\mathbf{0 . 0 0 2 6 4 0 -}$ \\
\hline $\mathbf{R}$ & 0.014965 & $\mathbf{R}^{\mathbf{2}}$ & 0.000224 \\
Sig & 0.196 & F value & 1.675 \\
\hline
\end{tabular}

These results are consistent with studies that examine the weak-form of market efficiency of PEX, Results of the parametric tests are consistent with the alternative hypothesis which states that stock market is inefficient at the weak-form level as the indices exhibited autocorrelation and stationary behavior. Meanwhile, results of the runs test also support the inefficiency of the market as the major index found to be following a pattern rather than a random walk (Alkhatib and Harasheh, 2014). Abushammala (2011) study tested the efficiency by using the daily prices at the period from January 1st, 2007 to December 31st, 2010. The study covered the daily prices of the general index, in addition to Al-Quds index. The Researcher, through statistical measures proved the inefficiency of the (PEX) in the weak level. The market did not respond to all political events and it can be assumed that these events were lesser important.

These results are also consistent with Najaf et al. (2015) study which explored the relationship between political events in Pakistan on the stock market development between (2011-2014), the results of the study have shown that there is no significant relationship between stock market returns and political events. Cutler et al. (1989) study proves that political factors did not significantly affect stock returns in the American stock market; recently Dhea Permana (2016) investigates whether the Indonesian Presidential Election in 2014 generates a positive market reaction. Study found that the average return does not react to the Indonesian Presidential Election of 2014.

The study has suggested that the people of Palestine absorb political instability and uncertainty quickly and it has become a part of their life and it is just a common phenomenon for them. The people react for short period of time and after that they absorb the noisy information. In other word, political uncertainty has become certain in peoples life.

\section{Conclusions}

1. Mean Index returns before and after the political events are not different. $\left(m_{1}=m_{2}\right)$.

2. Mean Index returns before and after favorable political events are not different. $\left(m_{1}=m_{2}\right)$.

3. Mean Index returns before and after the unfavorable political events are not different $\left(m_{1}=m_{2}\right)$.

4. There is no significant impact of the political events on the Index returns.

\section{Recommendations}

The study employed the Market Model (index) to estimate the normal stock return, another model exists and gives different results. One of such model is $\mathrm{CRACH}$ which takes care of heteroscedasticity effect. A future study based on this model is recommended. Analysis can be made on the industry level. The study can also examine the impact of these events on individual stock or and portfolios. Both companies and the PEX should provide more details and explanations about the reasons behind stock price movements. This also applies to sudden swings in stock price of individual companies.

\section{References}

1. Abushammala, S. (2011). Testing the weak form efficiency of Palestine-exchange. International Journal of Economics and Finance, 3(6), 244-253. 
2. Addoum, M., \& Kumar, A. (2016). Political Sentiment and Predictable Returns. The Review of Financial Studies, Volume 29, Issue 12, December 2016, pp. 3471-3518.

3. Akram, A. and Murad, H. (2013) 'Testing the weak form market efficiency: Empirical Evidence from Palestine Exchange (PEX)', Proceedings of 6th International Business and Social Sciences Research Conference, 3 - 4 January, 2013, Dubai, UAE.

4. Alam, A. (2013). Terrorism and Stock Market Development: Causality Evidence from Pakistan. Journal of Financial Time, 20, Pp. 116-128.

5. Asteriou, D., \& Sarantidis, A. (2016). Political Instability and Stock Market Returns: Evidence From Oecd Countries. Economics and Business Letters, 4(5), 113-124.

6. Cutler, D., M., Poterba, J., M., Summer, L., H, (1989). What move stock prices? Journal of portfolio management, 1989. Issue 15. pp. 4-12.

7. Dhea Permana, (2016) Relationship between Political Stability with the Market Performance. (Case Study on Jakarta Composite Index. International Journal of Management and Applied Science, Volume 2, Issue 7, pp.22-26.

8. Diamonte, L. \& others. (1996). Political Risk in Emerging and Developed Markets. Financial Analysts Journal, 52(3), Pp. 71-76.

9. Fama, F. (1970). Efficient Capital Markets: A Review of Theory and Empirical Work. The Journal of Finance, 2(25), Pp. 383-417.

10. Hayes, N. (1998). Cross-Border Currents: Country Risk Revisited. Journal of Lending and Credit Risk Management (80), pp. 61-61.

11. Hira, I. (2017). Relationship among Political Instability, Stock Market Returns and Stock Market Volatility School of Economics, Finance and Banking. Studies in Business and Economics, 2(12).

12. Huang, T., \& Zhang, B. (2015). International Political Risk an Australian Con-Text. Journal of Banking and Finance, pp. 393-405.

13. Ian, B. (2007). The Fat Tail: The Power of Political Knowledge for Strategic Investing. New York: Oxford University Press.

14. Lam, S., \& Zhang, W. (2014). Does Policy Uncertainty Matter For International Equity Markets? Basic Research Working Paper Pp. 1-48.

15. Lehkonen, H., \& Heimonen, K. (2015). Democracy, Political Risks and Stock Market Performance. Journal of International Money and Finance, 59, pp. 77-99.

16. Li, J., \& Born, A. (2006). Presidential Election Uncertainty and Common Stock Returns in the United States. Journal of Financial Research (29), pp. 609-622.

17. Najaf, K., \& Others. (2016). the Impact of Terrorism and Political Events on Stock Market: Empirical Evidence from Pakistan. International Journal of Scientific Research and Management, 3(6), pp. 3036-3045.

18. Ramcharran, H. (2003). Estimating the Impact of Risks on Emerging Equity Market Performance: Further Evidence on Data from Rating Agencies. Multinational Business Review, 3(11), pp. 77-90.

19. Wang, Y., \& Lin, C. (2009). The Political Uncertainty and Stock Market Behavior in Emerging Democracy: The Case of Taiwan. Qual Quant (43), pp. 237-248.

20. Center for strategic and international studies. (2017). Retrieved from center for strategic and international studies: http://www.csis.org

21. Palestine Exchange (2017). Retrieved from Palestine exchange official website: http://www.pex.ps 